\title{
Ethics in the Exercise of Psychology
}

\author{
Norma Coffin Cabrera*, Sandra Angélica Anguiano Serrano, Benita Cedillo Ildefonso, Juan José Yoseff Bernal, María del Refugio López \\ Gamiño and Patricia Suárez Castillo \\ National Autonomous University of Mexico, Campus Iztacala. \\ *Corresponding Author: Norma Coffin Cabrera, National Autonomous University of Mexico, Campus Iztacala.. E-mail: coffin@unam.mx \\ Received Date: December 18, 2019; Accepted Date: February 13, 2020; Published Date; February $18,2020$. \\ Citation: Norma Coffin Cabrera, Sandra Angélica Anguiano Serrano, Benita Cedillo Ildefonso, Juan José Yoseff Bernal, María del Refugio López \\ Gamiño and Patricia Suárez Castillo, Ethics in the Exercise of Psychology, J. Psychology and Mental Health Care. Doi: 10.31579/2637-8892/068
}

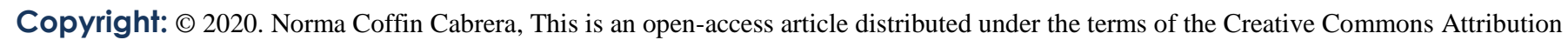
License, which permits unrestricted use, distribution, and reproduction in any medium, provided the original author and source are credited.

\begin{abstract}
With the recent approval of the new curriculum for the Psychology career at the National Autonomous University of Mexico, campus Iztacala, and based on the fact that contents of ethics appear in the different subjects, this paper intends to provide a consultation document regarding the ethical guidelines that must permeate our profession in its different fields. The subjects discussed here allow introducing teachers and students of the career to the ethical principles that must regulate teaching, research and service in Psychology. It also addresses what are the Ethics Committees and their role. The importance of this article is its contribution in presenting the universal principles of ethics applied to the fields of Psychology in any university curriculum.
\end{abstract}

Keywords: curriculum; ethics; research; teaching; service

\section{Introduction}

This paper aims to support that psychology cannot disregard ethics, which is consubstantial (rather, co-existential) to its epistemological claim in addressing its object of study. Consequently, every psychologist not only has their own values (in their universality and particularity), but they must be present and 'on alert' when the psychologist approaches to investigate the lives of people and their claim is to contribute to their personal (and social) change. These two objectives will correspond to two sections that will make up the body of the work. The one is based on the person of the psychologist, who as such has his own values, his ideals, expectations and desires. But this personal matter of the psychologist should not be confused with the values, ideals, expectations and desires of the people who come to him for support. They can be in concordance, in dissonance, in collision or in tension towards the poles of positivity or its opposite, negativity. How to govern? In this work it is assumed that the psychologist has to be a connoisseur of his own culture and protect himself from ethnocentrism - which, for the rest, and according to Ochs and Schieffelin, 1984, has been the mark of his behavior because the study of its own culture and that elevates the rank of the universal; when it is still particular to its own culture, or group of belonging.

In other words, one thing is what psychology has done in how we become individualized subjects and another is how this individual freedom is included in the horizon of what our western cultural heritage is, although psychology, cultural as it should be, it has to formulate a universality that we have found with human rights.

It is therefore the objective, to formulate an epistemology in which fact and value are the object of study of psychology as facts and values carried out by individuals living in an organized society with principles formulated by itself (as Castoriadis reiterated, 1988), but also to formulate that the psychologist as an active member of said society has to be given principles of behavior to contribute with his actions to that intended ideal of peaceful coexistence.

The nineteenth century, starting point from the point of view that psychology is a moral science. cited here:

The words of Baldwin (1901, as cited in Brikmann, 2011, p.8)

“... in James Mark Baldwin's classical Dictionary of Philosophy and Psychology, the moral sciences are defined as: "Those branches of inquiry which deal with mind and conduct, as opposed to matter and life; i.e. they are contrasted with the physical and natural sciences, and are often described as the "mental and moral sciences". In this general division all knowledge of man, apart from his body and its history, falls to the moral sciences; history, political economy, law, and statistics, as well as psychology, anthropology, and ethics...."

Of course, this way of seeing psychology as a science of behavior and of mind, comes from Pinel's psychology, and that in general, allowed distinguishing medicine from psychology. One was considered simply as medicine, and psychology as mental medicine.

Thus, Baldwin does nothing more than recognize what was a common place, to distinguish psychology from medicine. But also, to put the accent on conduct (this is a term, which in Foucault, 1976, is consigned in its moral sense of people's doing), that is, to give a value to the person's action. The term is linked to acting through a guide or acting being carried by someone or something.

Dewey (2003) in one of his last writings considered that pragmatism as a philosophy should contribute to the democratic life that was projected on the horizon of the world, once the second great world war was being lived. A premise of its formulation was based on the fact that individual and freedom are a couple that goes hand in hand, that is, 
individuality is promoted because on the horizon of democratic life is that maximum freedom is possible by leaving it in the hands of the own individual (of this one, but also of all that he recognizes as with partners), his realization of the common good. The reason for individualization is in the search for the common good, therein lies the reason for the existence and promotion of individualization as the force of community life itself. They are of mutual constitution, or if you want, transactional.

\section{Definition of Ethics}

Ethics is considered the science of human behavior that studies the way men act in front of their peers, as well as the way in which they work in their daily work and professional activities (appointment). As a discipline, it appears with Socrates in the 5th century BC., who stated that good or bad not only occurs from the collectivities, but also for the reason of man making it possible to establish universal criteria to govern one's own behavior. Ethics is particularly relevant from the events during the Second World War related to research conducted with humans by the Nazis in the name of science. The Nuremberg code in 1947 and later, a year later in 1948, the Declaration of Human Rights seeks to eliminate such practices. Also, the doctrine of informed consent that extends to medicine and biological sciences in the first instance and little by little to the rest of the disciplines and professional practices is booming. Various groups of professionals have developed ethical codes that seek to regulate professional practice, among them, the Code of Ethics of the Association of American Psychologists and the Code of Ethics of the Mexican Association of Psychology are of particular relevance to our profession.

\section{Moral and Ethics}

Ethics and morals are closely linked. On the one hand, morality is considered a system of beliefs and values that are tacitly shared between individuals who share the same language, who live in the same geographical space with equal or similar customs and, which have been inherited from generation to generation. This belief and value system allows individuals to identify themselves as part of the social group to which they belong. Strictly speaking, the word moral is derived from the Latin "mores" meaning customs (García \& Ruíz, 2010).

Morality arises with the existence of man and is considered a set of rules, values, taboos and prohibitions imposed from the environment where the individual develops (customs, religion and politics). Morality is changing since it is determined by the values of a given society.

On the other hand, ethics is a rational and critical reflection on the validity of human behavior, it implies an analysis of the rules or values established by society. According to Rodríguez (2005), ethics is a philosophical reflection about the codes of norms imposed on societies in order to regulate the behavior of the individuals that constitute it. In ethics, what is considered good or bad is not only given by the community to which it belongs, but the reason that belongs to the individual comes into play. The reason, allows to establish a universal or natural criterion to govern the conduct itself, critically analyzes the validity of the conduct of man, the rules or values established by societies. In this sense, ethics currently according to the author, is considered the science of human behavior that focuses on the study of individuals in front of other individuals, as well as the ways in which it develops in their work and professional activities of the day day. Ethics includes, in its analysis, all human activities; One of these, scientific research, has gained increasing strength and concern above all for the rise of genomic research. Research with living beings, including man, gives rise to what is currently known as bioethics. Bioethics Despite the efforts made in the Nuremberg code and in the 1948 Declaration of Human Rights, the transition to a culture of ethics in the disciplines has been slow. Until 1970, this is 23 and 22 years later Potter (1971), used for the first time the term bioethics in his article "Bioethics: the science of survival". In this document, several principles are proposed:

1. Principle of autonomy. Considers that all people are autonomous and this principle should be respected as a rule, except when situations occur where people are not or have decreased autonomy (minors, people in vegetative state or with brain damage, etc.). It implies that everyone has the right to decide whether or not to participate in investigations or if certain treatments and of course, to be informed of them. The ultimate expression of this principle is consent informed.

2. Principle of beneficence. It constitutes the obligation to always act for the benefit of others, without causing damage and promoting their legitimate interests.

3. Principle of non-maleficence. This principle seeks not to carry out actions that could cause harm or harm others. It requires a solid and extensive theoretical training practical discipline.

4. Principle of Justice. Treat everyone accordingly to reduce inequality of any nature: ideological, social, cultural, economic, etc. In other words, treat equals equally and unequals.

Bioethics as a branch of ethics, focuses on the analysis of the problems of human behavior; in the field of application, its objective is to ensure human and non-human life by extending its field of action towards aspects related to the environment and the treatment due to animals (Rodríguez, 2007).

Ethics and teaching, so far it seems that ethics and bioethics only relate to those aspects linked to the protection of life, the integrity of species and the environment in a biological sense, however, the social groups and relationships that derive from their interactions They can also affect man in a psychological and social sense. In these terms, one could well speak of socioethics, which, taking up the same principles postulated by bioethics, seeks to protect individuals from the actions of others that may harm them in certain contexts. As an example of the above, ethics in teaching can be mentioned where it is intended that the relations between teacher-student, student-student and student-authorities be governed by ethical principles.

Küng and Kuschel (2006), mention that education in values must play a leading role in all education. Without guidance regarding ethical issues, values and meaning, the central aspect of responsible emancipation is lacking. This means that issues related to meaning, values and ethics represent a genuine scope of school education tasks, related to the ideological tradition and present to which it is better to accommodate in a school subject, without Therefore, the other subjects or extracurricular education are downloaded from this task. Likewise, these authors establish that the educational effort in the sense of world ethics is an education of truthfulness, tolerance and mutual respect. The declaration on world ethics has devoted special attention precisely to this area.

According to Bombino et al (2011), the human being is not born as a moral and axiological entity, but it is necessary to form it. The purpose of the educational process is much more than developing information. It is the unity of the instructive and the educational, for man must be understood in his narrow unity of the rational and the emotional. Not for pleasure, the supreme task of education is the humanization of man, the appropriation of values, customs, traditions, which ultimately occurs through the apprehension of national and universal culture.

Bombino et al (2011), establish that this is a process that occurs to the same extent that educational policies are incorporated by new generations. Hence also the value of educating according to the desirable 
personality patterns for each society. In turn, when the values carried by the teacher are legitimate, authentic, students feel identified with the educator. If the teacher is genuine, the values of the society to which we aspire are expressed.

Discussing and hearing students, regardless of what they say, whether we agree with them or not, is essential for them to feel identified with the educational process; Only if we let the students express themselves, we achieve the originality we aspire, even if they are wrong. Therefore, if there is no room for error, flexibility, dialogue, it becomes difficult to achieve authenticity in the moral or axiological formation of current generations and, therefore, achieve a virtuous man (Bombino et al, 2011).

This author mentions that it is precisely the quality of the relationship and the human bond that can change the style of communication with the student, which can produce, in turn, changes in their personal growth and values. Likewise, for someone to be a model they have to become a kind of moral mirror where people who are part of their group and their social environment are looked at daily.

Thus, the educational process, as long as it works with the necessary efficiency, has as its object, among other attributions, the intellectual, physical, moral and axiological perfection of people.

These four moments, linked with others no less important and of great value for the educational process, have as their main objective to promote improvement, human growth and, in short, to influence the integral formation of men and women. In this sense, for Bombino, the teacher is an essential entity, because when the values that the educator carries are authentic and legitimate, the students, who become vital in this process, feel identified with they. Therefore, it is important not to confuse the fact of informing with training, because we can simply remain or not in the students' memory. Nor should it be forgotten that the teacher assumes authentic behavior in the plan of behavior and communication with his students, as well as the educational community as a whole, in him the values that characterize the educational work will also be present.

Bombino et al (2011), establish that values such as solidarity, respect for others, freedom, among others, cannot be transmitted if the person who transmits them does not experience them. Values education is not only vital for students, it is also for teachers. Some authors talk about the education of educators. Rescuing and giving meaning and strength to the idea that the teacher also needs to be educated, this is formed.

Thus, it becomes essential that man - call himself an educator, student or manager - reach a level of axiological internalization as optimal as possible. It is about the subject or subjects involved in this process, achieve or achieve levels of relevant moral and axiological development and full of human attitudes, expressed or embodied by the subject in the exercise of their daily behavior. The real adequacy and effectiveness of the value is indispensable for the teaching-learning process. (Bombino et al, 2011).

While it is true that the assignment of issues to discuss in a given forum can fulfill its mission, it is also indisputable that this task or activity has to be carried out with the essential professionalism, because otherwise, it can become, and not rarely has happened, in a frank formalism, losing all its sense and formative effectiveness, as well as its degree of ethical implication (Bombino, de Armas \& Porto, 2009).

On the other hand, we have seen the emergence of ethical problems in academia in universities (Koocher and Keith-Spiegel, 1998). An unacceptable number of incidents involving racism, sexual harassment and academic dishonesty permeates the reputation of higher education. Campus scandals range from special benefits for athletes, to scientific misconduct, which receives more public attention than positive contributions from teachers and students. Negative publicity in terms of inflation in grades or grades, huge class readings, excessive dependence on exams for objectives and teaching assistants make one wonder what really happens behind doors. Regarding freedom of expression, higher education institutions struggle with what can and cannot be pronounced in a public forum and even a private conversation. University communities, as mirrors of society, are not exempt from developing a tendency to avoid personal responsibility and blame others for real or perceived deficiencies. Increasingly, universities are subject to lawsuits for bizarre reasons. There was a case in which a patient, who had sued his therapist and the clinic that employed him, tried to take legal action against the university in which the therapist had studied for failing to secure the competences of his graduates (Custer, 1994).

According to Koocher and Keith-Spiegel (1998), a cut in resources invariably leads to competition between academics for the team, per diem, laboratory spaces and promotions. This shortage leads to tension, which is revealed through explosive and low moral discussions among faculty members.

Ethical codes briefly touch ethics in teaching. The assumption that ethical inaccuracies are handled within the institution probably account for a relative interest in having external sources that establish lines for academic psychologists. A teacher's behavior, however, generally must involve a huge violation before formal action is taken at school. Even if the institutional channels are functioning in a way that allows fair hearings and due process, only the most assertive students seem to use them. Students may feel helpless and inadequate, which makes it difficult for them to seek formal compensation to their grievances. Thus, many students accept the self-test for their discontent.

Finally, an implicit "pact of silence" may exist between students and teachers, in which teachers perform less-than-adequate work, requiring less-than-adequate performance of their students, leaving any person involved free of do something else with your time. These authors argue that there are complaints about the programs, which are rarely reviewed by an ethics committee or professional organizations, perhaps because their descriptions are brief and general, leaving little to debate. In this way, an ethics committee is an unlikely possibility of compensation between the teacher and the student.

When the component of a course is augmented, changed or deleted, the correction must be made in the current program. If this is not possible, students must be informed by other means, and they must certainly be notified on the first day of school. There are ethical complaints about the inconsistencies between what the program says and what is taught.

The same should happen with the forms of evaluation. They must be attached to the program, and clearly defined, without requiring prior knowledge that has not been taught.

With respect to academic assessments, Koocher and KeithSpiegel (1998), mention that they are based on the information and tasks that each educational offer makes to the student. These factors, however, cannot excuse the academic psychologist from his ethical and personal obligation to invest a considerable effort in educating and evaluating his students fairly, based on his current execution and within the established time frame. Ethics committees cannot attract these cases, unless the student has documented negligence or harmful assessments. It is for this reason that they are attentive from the first day, to receive their program and way of evaluating, clarifying their doubts. 
As for the skills and preparation of the course, these authors mention that it is an assumption that psychologist professors obtain a continuing education, teachers are supposed to consistently update their knowledge and attend professional meetings, meetings and conferences. Students do not realize that psychologist professors who are poorly prepared, or who cite ancient sources and theories in a topic (when there are more recent and recognized theories available), are missing the ethical requirements of their profession. While most of the complaints received in ethics committees about educating psychologists are frequently associated with the way of assessing and offensive interpersonal styles, few complaints about the teaching skills and professional preparation of teachers.

Likewise, they point out that undergraduate education does not necessarily represent the skills and areas of interest that last throughout a career. Sometimes, psychologists decide to teach in an area where they have not received, or insufficiently, formal training. Quite often, and more in small schools, teachers can be assigned subjects in which they have rudimentary knowledge. They are generally offered courses that can enable them to teach that class.

When teachers place their own needs above the welfare of their students, abuse results. Because there are students who want to please their teachers, they can allow them to be mistreated. Or, because students can benefit from participating in activities that also meet the needs of teachers, (as in research), they may not recognize the point at which collaboration becomes exploitation. Research collaboration with students is very popular due to the benefits they can bring to those involved (KeithSpiegel, 1991; Keith-Spiegel, Tabachnick \& Spiegel, 1994).

With regard to different problems that arise between teacherstudent and teacher-teacher relationships, it is important to clarify that sexual harassment is not an issue for ethics committees. It is a crime, and must be formalized in the relevant legal instances. Ethics committees do not attract crimes. In these cases, there is no ethical debate, since the offender totally lacks it. Corruption is also a matter concerning the lack of ethics. A teacher who does not attend his class, when he is paid for it, is committing an act of corruption that must be reported by the students. A teacher requesting payment in exchange for a grade is a case of corruption that must be reported. Failure to report these situations makes the student complicit and corrupt at the same time.

\section{Ethics at the National Autonomous University of Mexico.}

In the case of our institution, the National Autonomous University of Mexico (UNAM), promotes as institutional values among the university community those shown in Table 1.

\begin{tabular}{|c|c|}
\hline Legality & Act according to rules and laws. \\
\hline Creativity & Search for a different way of doing things, new solutions to known situations \\
\hline $\begin{array}{l}\text { Environmental care } \\
\text { Innovation }\end{array}$ & $\begin{array}{c}\text { Protection of the world in which we live, ensure the well-being of all living } \\
\text { beings on the planet. }\end{array}$ \\
\hline Passion & $\begin{array}{l}\text { Use of knowledge or its generation for the creation of new products, services } \\
\text { and processes; go beyond the established and conventional. }\end{array}$ \\
\hline Perseverance & Delivery and enthusiasm to do things well beyond the fulfillment of duty. \\
\hline Academic integrity & Keep track of objectives and goals overcoming difficulties. \\
\hline Solidarity Equality & $\begin{array}{l}\text { Act with honesty without lying, plagiarizing, inventing data, or cheating in the } \\
\text { activities that correspond in the academic field, both in teaching, research or } \\
\text { dissemination. }\end{array}$ \\
\hline Quality of life & $\begin{array}{l}\text { Create support networks to help those who need it, when they need it; It implies } \\
\text { disinterest in expecting something in return. }\end{array}$ \\
\hline Commitment & $\begin{array}{l}\text { Regardless of their gender differences, ethnicity, socioeconomic status, identity } \\
\text { or sexual orientation, intelligence, physical appearance, status or any other. }\end{array}$ \\
\hline Equity & General well-being of people and societies. \\
\hline Eagerness to know & $\begin{array}{c}\text { Ser fieles a las decisiones productos de nuestra libertad, continuar en la } \\
\text { dirección elegida para alcanzar los beneficios. }\end{array}$ \\
\hline Responsibility & General well-being of people and societies.. \\
\hline Secularity & $\begin{array}{l}\text { Investigate and investigate the world to understand and transform. I am amazed } \\
\text { by reality. }\end{array}$ \\
\hline Respect & $\begin{array}{l}\text { Respond to the consequences of our actions with maturity, wisdom, honesty and } \\
\text { courage. Take care of yourself and those who depend on us. }\end{array}$ \\
\hline Autonomy & Respect for beliefs and ideas. \\
\hline Respect & $\begin{array}{l}\text { Have consideration for others, near and not near, human and non-human, not } \\
\text { taking what is not ours, listening without disqualifying, not harming or ignoring } \\
\text { others; share space without invading others, not disturbing the tranquility or } \\
\text { work of others. }\end{array}$ \\
\hline Freedom of expression & $\begin{array}{l}\text { Think and say what you want regardless of whether the opinions are correct, } \\
\text { true or prudent. }\end{array}$ \\
\hline Honesty & Act with transparency, congruence and sincerity. Be trustworthy. \\
\hline Tolerance & $\begin{array}{l}\text { Support or admit the differences we have with others, regarding our opinions, } \\
\text { beliefs, sexual orientation, preferences, ways of life, speaking and acting. }\end{array}$ \\
\hline
\end{tabular}

\section{Source: Values UNAM. Copyright 2015. http://www.dgcs.unam.mx/valor/Valores.html}


With the aforementioned values, the training of competent and informed students, with social sense and national conscience (Institutional Framework of Teaching, 1988) is intended for a better future in the individual and social. In the case of the teacher, the right to express their opinions is established without greater restriction than respect and tolerance.

\section{Bioethics Committees}

The emergence of bioethics as a field of study and application establishes the basis for the emergence of the Bioethics Committees. The United Nations Educational, Scientific and Cultural Organization (UNESCO in Spanish), in 2005, publishes a guide for the Bioethics Committees. In this guide, he points out that every bioethics committee should be systematically charged with addressing the ethical dimension in three major branches of knowledge: a) health sciences, b) biological sciences and c) innovative health policies. It is composed of various experts, is multidisciplinary and its members analyze and discuss issues and problems of a bioethical nature.

The general objectives of the Ethics Committees according to UNESCO (2005) are: Contribute specialized knowledge and analyze ethical issues related to biology, medicine and biological sciences

- Improve the care provided to patients

- Improve the benefits perceived by the public

- Protect patients and healthy participants involved in physiological, biological, behavioral or epidemiological research trials.

- Facilitate the acquisition and application of new knowledge aimed at improving health and care services.

- To accommodate various points of view and different disciplines to harmonize the freedom of research and scientific and professional knowledge with the concerns raised by human rights and the common good.

- They settle for multidisciplinary teams.

- They use problem-solving strategies where the decisionmaking process is immersed.

The committees may be created at different levels: 1) national, 2) regional and 3) local.

Additionally, four types of bioethics committees can be formed: 1) normative or advisory Commitee, 2) professional medical associations (AMP), 3) medical or hospital ethics (CEMH) and 4) research ethics (CIS).

Each of these committees will have differentiated objectives, so in the first case, the Normative or Advisory Committee (CNC in Spanish), must focus on establishing solid policies in the scientific and medical field; in the second, they will establish good care practices; The third objective is to improve the care provided to the patient in the different professional practice scenarios: hospitals, outpatient or outpatient clinics, chronic or long-term care centers and hospices; Finally, the fourth case aims to protect human beings who participate in research for the generation of biological, biomedical, behavioral and epidemiological knowledge.

In this guide it is proposed that normative or advisory commitee have a maximum of 40 members and a minimum of 18 . The idea that underpins such a proposal is the consideration that, if the size is small, efficiency and consensus prevail and uniformity of opinions prevails while, if It is large, there is greater representativeness and diversity with the decrease in efficiency and internal coherence. Members are required to have specialized knowledge, representativeness is another criterion, as well as experience.

With regard to Professional Medical Associations (AMP, in Spanish), they are voluntary affiliation associations and usually establish guidelines for their members to respect ethics in their research practices, they also prepare their members to strive to protect the public from improper practices of its members, in this sense, promote the selfeducation of its members. The size of these committees of 40 to 50 members makes the formation of subcommittees necessary. The selection criteria are not different from those of other committees.

On the other hand, it is suggested that the Medical or Hospital Ethics (CEMH, in Spanish), have the purpose of guaranteeing practices relevant to the decisions taken in relation to the medical care offered to help patients, without prejudice to the relationship between the doctor and the patient; It organizes activities for self-education, development of guidelines and policies of its workplace, also studies cases from the perspective of bioethics and not only from a medical perspective. In the integration of these committees there are regularly professionals from different disciplines. Its center of attention is located in the protection of the decisions taken by the patients trained to accept or refuse medical treatment and, on the other hand, to protect the health care centers and those who work in them from legal responsibilities. The size of the committee is suggested to be 15 to 25 members.

Finally, in relation to the research Ethics Committee (CIS, in Spanish), is mentioned that the use of animals in research, behavioral, biological or biomedical has always raised controversy related to the pain and suffering that animals suffer during the investigation processes, it is sought that as far as If possible, animal models are replaced by other types of models or replace vertebrates with species with less sensitivity to pain. This will be discussed later.

These committees also address the protection of humans who participate in these types of research: biological, biomedical and behavioral, considering that some people may be harmed. In this direction it is proposed that all those involved in these types of research understand the bioethical policies and concepts, the guidelines and regulations applicable to animal and human research. These committees should be made up of informed and interested people and not just health professionals or scientists. Its size is recommended to be from ten to twenty people.

Ethics in the new curriculum of the Psychology degree

In College institutions dedicated to the training of human resources for health care and the generation of knowledge, the National and International Rules related to the ethical actions derived from the exercise of teaching, community care and research in all your expressions and levels must be present.

In the Campus Iztacala, of the National Autonomous University of Mexico, a new curriculum for the Psychology degree was approved; all theoretical, methodological and practical subjects will address the ethical principles that should govern the work of the psychologist. The purpose of the work is to contribute to the implementation and development of ethical content in the subjects to strengthen the ethical culture in vocational training, linking the institutional values of the profession and research with the principles of human rights of people.

In accordance with the above, it is necessary to generate a culture within the psychology career, the ethical exercise in teaching, research and professional service. To achieve the above, various actions are required.

\section{Actinos}

A) Identify in the current population of students and the main ethical dilemmas they face in the face of teaching, research and community service.

B) Structure a manual of ethical dilemmas that allows the analysis and reflection of students and teachers, as well as their ethical approach.

C) To continuously evaluate the training and ethical development of teachers and students. 


\section{Bioethics in animal research}

The use of animals in scientific experimentation has been and will be of vital importance for human life, as well as the benefit obtained from research will improve their well-being.

Thus, the use of animals has facilitated the knowledge of biology and physiology in science to perform diagnoses and treatments that improve the quality of life of man. Therefore, the use of animals in experimentation and teaching must be carried out with respect and taking into account the reactions of the animal and its own ethology (Fernández \& Heuze de Icaza, 2007).

Experimentation with animals is accepted by consensus, only if it is carried out under the agreed conditions and with the guarantee of humane treatment with animals. The first condition of the researcher who works with laboratory animals is respect for life, for pain or suffering to which they can be subjected in the work under their responsibility (Cardozo \& Mrad de Osorio, 2008).

Álvarez-Díaz (2007) highlights the following principles: of refinement to relieve or minimize the pain, suffering and stress of animals, seeking their welfare, but without affecting the outcome of the experiment. Contemplating to improve the living conditions of the animals and their diet, administer analgesia and anesthesia when warranted, reduce the application of injections and the volume administered with needles of the smallest size and caliber possible, be clear about the parameters to be measured in the experiment, select less invasive methods and the right species, and use the most humanized euthanic procedure if required.

Currently it has not been possible to dispense with experimental animals, even with methods: physicochemical, mathematical and computational models (quantitative structure-activity interrelation, design of drugs with computational help, mathematical models of biochemical and physiological processes), the use of inferior animals, use of vertebrates in early stages of development, tissue culture and methodologies ex vivo (or in vitro), studies in humans (when sometimes they are the only ones that can be used as research subjects), use and extrapolation of information existing, among others (Rodríguez, 2007).

The use of animals in experimental research by scientists, represent a great source in scientific progress especially in biomedicine.
Since it has allowed to study the causes, origin, treatments of diseases both in humans and in the animals themselves, as well as discover ways to heal and control diseases, for example, studies on cardiology, cancer, transplants or HIV/AIDS (Aguilar, Coyo \& Giménez, 2012), as well as surgical techniques and the development of effective drugs. Implementing the rules on causing the least possible damage in their experimental use, ensuring their well-being, as well as their production, transport, intervention until sacrifice among others.

It is important to note that there are also experimental scientists who are against the use of animals for the testing of products intended for use by humans. Arguing that they are not human beings and, therefore, the results obtained from the studies carried out on them will be partially extrapolated to human beings due to species differences, and that these results could coincide by chance. Two main institutions stand out: Medical Research Modernization Committee or the Doctors and Lawyers for Responsible Medicine group (Boada, Colom \& Castellò et al., 2011).

Thus, animals in experimental research are key to scientific progress in general, and the use of them must be governed by the application of bioethical principles. Nowadays, animal research must be reviewed and authorized by the bioethics committees in universities and research centers, where the ethical aspects of the experimental methodologies used are reviewed.

In practice, the care of laboratory animals rests with several people, but legally and depending on the laws of the country where the study is carried out, the final responsibility often lies with the principal investigator who is performing the scientific procedure. For which he is responsible, to take precautions in the reproduction, maintenance and use of animals for scientific research purposes, they will be supervised by qualified and competent professionals in the field and should allow the growth, maturation, reproduction and normal behavior of the animals. Animals, in accordance with the standards issued by the institution itself (Regulation of the General Health Law on Health Research, 2005).

For this, there are norms and regulations that have been promulgated in the world and that despite having a sufficiently theoretical basis, they have not been internalized in the human being in front of the responsibility they have with the other living beings that inhabit the planet (De Aluja , 2002). (See Table 2).

\begin{tabular}{|c|c|}
\hline Country & Normative \\
\hline USA & Guide for Laboratory Animals Facilities and Care, 1963 \\
\hline & Guide for the Care and Use of Laboratory Animals (NIH Guide, 1985 \\
\hline European Community & Directive86 / 609 / EEC on the protection of Animals used in experimentation, \\
& 1986. Directive 88/320 / EEC, 1988 \\
\hline & $\begin{array}{c}\text { Directive 2004 / 9-10 / 10CE on inspection and verification of good laboratory } \\
\text { practices. Parliament and of the Council, 2004. }\end{array}$ \\
\hline England & Cruelityto Animal Act. 1876 \\
\hline Canada & Federal law, article 446 of the Criminal Code. advice \\
\hline Switzerland & Canadian Animal Protection (CCPA), 1968 \\
\hline & Environmental Protection Act and Ordinance. General Law \\
\hline Mexico & 1988 \\
\hline & Official Mexican Standard. Technical Specifications for \\
\hline & Production, care and use of laboratory animals. \\
\hline Colombia & NOM-062-ZOO-1999. \\
\hline & Law 84 of 1989. The National Statute of \\
& Animal Protection \\
\hline
\end{tabular}


It is important to highlight that the first scientists who addressed the bioethical problems of the use of experimental animals, were Zoologist Russell and Burch (1959), who developed "The Principles of Humanitarian Experimental Techniques" in 1959. This principle seeks to guarantee The rational and respectful use of the experimental animal, has been summarized in the triple principle of substitution, reduction and improvement, means that researchers should seek, whenever possible, alternative methods to replace the use of live animals with insensitive materials, reduce the number of animals used and refine techniques to reduce the pain and suffering of experimental animals (Cardozo \& Mrad de Osorio, 2008). The application of the Three Rs implies that the researcher expresses his values, awareness and respect towards the life of other living beings, which on the other hand guarantee the quality and validity of biological and biomedical research.

However, yes, in the investigation processes damages occur to any living organism and to the environment, the criminal laws linked to those crimes, in force in the country will be applied. Thus, the international sphere has promoted reflection for life. Where it is sought, not putting the research subjects at risk without any reason or justification, if it is done, it becomes an unacceptable experiment (Cardozo \& Mrad, 2008).

Even so, social movements have been formed that are in favor of the absolute prohibition of using experimental animals. Creating conflicts with biomedical research that requires the prior conduct of experimental tests on animals, before being performed on humans.

Some of the reasons why animal research is done, is because the study of the behavior of animals (non-human) is simpler, the basic processes are studied more easily and the records can be performed for periods of time longer. The observations are not complicated with social relationships between the subject and the experimenter, reaching greater control over the conditions: Managing genetic stories to control certain variables and stories of special life to control. Control of current circumstances, which in human behavior is unlikely (Rodríguez, 2007).

In Mexico, the Official Mexican STANDARD NOM-062ZOO-1999 was created, which establishes the technical specifications for the production, care and use of laboratory animals.

This STANDARD NOM specifies the characteristics that private and institutional bioteries must have in terms of their location, ventilation and activity areas; the acquisition of animals, the size of the cages for the different species; type of food; the obligations of the institution to monitor the proper functioning, hygiene and animal welfare; the type of personnel that you should have, as well as their preparation and the knowledge that you should have, as well as the indications about the transfer of animals, characteristics of the confinement and the type of transport, care during it. Guidelines regarding experimental techniques, anesthesia, analgesia, administration of fluids and other substances, obtaining blood and the permitted methods of euthanasia are given. It indicates the methods of biosecurity and occupational health for the staff.

On the other hand, it is important to note that the protocols in which animals are used must specify among others:

-The number of animals that will be used (statistically justify).

-Place, conditions and treatments to which animals will be subjected.

- The use of analgesics and anesthetics in accordance with the provisions of the Official Mexican STANDARD NOM-062-ZOO1999.

- Euthanasia method that will be used for animals, according to what is established in the Official Mexican STANDARD NOM-062-ZOO1999.

- Destination and final disposition of animals or bodies or their remains. Official Mexican STANDARD NOM-062-ZOO-1999.

On the other hand, thanks to animal research, scientists have discovered ways to heal and control diseases, as well as prolong human life. Some examples are:

- The discovery of the malaria cycle by Ross, in 1902, using pigeons as an experimental biomodel.
- $\quad$ http://www.animalresearch.info/en/medicaladvances/timeline/malaria-parasites-life-cycle-discovered/ - Theiler, in 1951, developed the yellow fever vaccine using primates and mice.

https://www.nobelprize.org/prizes/medicine/1951/theiler/biographical/ - De Duve, Palade and Claude discovered, in 1974, the functional and structural organization of the cell using chickens, guinea pigs and rats. https://www.nobelprize.org/prizes/medicine/1974/summary/

- Murria and Tomas, in 1990, using laboratory dogs, improved the application of techniques for organ transplants. https://www.nobelprize.org/prizes/medicine/1990/murray/25012-josephe-murray-nobel-lecture-1990/

- Lauterbur and Mansfield discovered, in 2003, essential aspects in the use of Magnetic Resonance Imaging (MRI) using clams, frogs, rats, mice, dogs, pigs and nonhuman primates. https://onlinelibrary.wiley.com/doi/epdf/10.1002/jmri.20035Use of Informed

\section{Informed Consent (IC) with Humans}

As for research with humans, and service to users, Informed Consent (CI) is an ethical requirement.

Informed consent is understood as any act of voluntary decision made by a competent person, by which he accepts or rejects the diagnostic or therapeutic actions suggested by the health personnel, based on the understanding of the information revealed regarding the risks and benefits that they can cause you (Caballero, 2016; WHO, 2004)

The ethical principles of the IC have their origin in the theory of principles, since this ethical system is the most used in bioethics because it is pluralistic and compatible with most value systems.

This theory has its origin thanks to the book: Principles of Biomedical Ethics, written by Beuchamp and Childress (1979, cited in Busquets, 2011), and is based on four principles: 1) Autonomy, 2) Charity, 3) Non-maleficence and 4) Justice.

The practice of informed consent derives from the principle of autonomy, which is the ability of the person to determine the course of their own existence and make their own decisions when they have the necessary information on the procedures or treatments to which they are going to submit The person must know the purpose, as well as the possible risks and benefits, and all the alternatives, it is also important that they know that they have the right to ask the questions they want and abandon the treatment if they decide, knowing the possible consequences of this decision. of decision. If the person is not competent to make their own decisions, then they can be taken by a legal representative. Within the practice of informed consent, the other principles such as Charity (principle of benefiting patients), Non-Profit (minimizing possible damages) and Justice (providing the best health care according to needs) must be included, in addition to the right to confidentiality (Cash, et., al, 2010)

This theory does not get rid of problems, since there is no welldefined model for resolvingethical dilemmas or conflicts between principles. Despite this, these principles have been the basis for deliberating and reaching consensus when making decisions in the area of health. The principles proposed by this theory were formalized as a way of making decisions in the United States, from the creation of a document known as the Belmont Report (1979) and which was prepared by the National Commission for the Protection of Human Subjects of Biomedical and Behavioral Research.

Although the literature refers to the medical and health field when talking about informed consent, in the field of psychology this step must also be put into practice in psychological research and psychotherapy. In this regard, Article 122 of the Psychologist's Code of Ethics states that the psychologist who is going to conduct an 
investigation must obtain the informed consent of the participants, using an understandable language for the participants, in addition to knowing clearly what the objective of the investigation, and have the freedom to participate, decline or withdraw from the investigation, knowing the consequences of these decisions. Article 119 of the same code states that when the person does not have the legal capacity to take their consent, then it must be obtained through an authorized legal representative. Likewise, Article 121 states that, for the realization of any type of electronic recording or recording, the patient must have granted permission to carry out this type of action.

With regard to the contents of an informed consent document, there are certain guidelines that must be taken into account when drafting it. Both in psychotherapy, as in research or studies, the objectives pursued, the expected benefits, the risks, discomforts and possible adverse effects must be specified, in addition to the fact that the therapeutic procedure, or the type of research strategies, must be clearly specified, as well as the foreseeable consequences in case this procedure or the alternatives are not performed.

The National Institute of Public Health (Instituto Nacional de Salud Pública, in Spanish, 2019), on its website, publishes different types of informed consent:

1) Informed consent letter for adults:

https://www.insp.mx/images/stories/comitesEvaluacion/comit Etica/docs/CARTA-CONSENTIMIENTO-ADULTOS.pdf

2) Letter for participation of parents and children: https://www.insp.mx/images/stories/comitesEvaluacion/comitEtica/docs /CARTA-CONSENTIMIENTO-PADRES-E-HIJOS.pdf

3) Letter for participation in any study or research: https://www.insp.mx/images/stories/comitesEvaluacion/comitEtica/docs /CARTA-CONFIDENCIALIDAD-INVESTIGADORESAS.pdf

4) Letter of consent for photos or video recording: https://www.insp.mx/images/stories/comitesEvaluacion/comitEtica/docs /CARTA-CONSENTIMIENTO-FOTOS-VIDEOGRABACION.pdf

Thus, IC is a tool that is mainly used in clinical settings, psychotherapy, and research issues, although what happens within the classroom should not be lost sight of.

A very widespread practice by several professors, is to make video recordings or audios in the classrooms, or to involve students in their research projects to participate as subjects of them, without using prior informed consent, which It constitutes a lack of ethics, since students are not being given the possibility to freely choose whether or not they wish to participate in any investigation, or if they wish or not, to be videotaped. Therefore, it is an urgent need that informed consent is also a tool that is included in the classroom for this type of activity.

A topic for debate and discussion about IC, should be the use of new technologies to provide psychological therapy, since in the 21st century it is increasingly common, to be a tool implemented by clinical psychologists. This new modality, although it has many advantages, such as facilitating that people who cannot physically move or who live in a very remote place have the opportunity to receive psychological care, also has its drawbacks, since in Mexico although there is the Code of Ethics The Psychologist, who serves as a guide for those who work in this area, does not exist as such a Procedures Guide for remote intervention as in other countries, which could have legal implications, both for patients and professionals.

In Spain, De la Torre and Pardo (2018) have developed a telepsychological intervention guide that brings together a series of recommendations, both ethical and legal for those who work online psychotherapy. In this guide they emphasize that through a legal text according to the privacy policy, the user must complete a data form on a specialized platform for this purpose, as well as request a written informed consent, in which the type is specified of technology and the media that would be used, as well as applications (ICTs), all this with an accessible and understandable language, in addition to ensuring that these technologies have security tools to protect privacy.

In Mexico, although online therapies abound, there is no security means or specific informed consent instruments for this type of intervention, therefore, it is one of the challenges that psychologists would have to develop together with other professionals, as engineers and lawyers.

\section{Conclusion}

Ethics in the training of the psychologist must link institutional, professional and research values with the principles of human rights; educational programs must contain horizontally and vertically intra and inter modularly, content of ethical reflection; Ethical training should be addressed to teachers and students continuously and finally, it is essential that student teachers participate in the identification of ethical problems and dilemmas in the teaching, learning, research and service processes for their approach and solution.

\section{References}

1. Aguilar, A.; Coyo, N. y Giménez, A. (2012): Bioética en experimentación animal. Universidad Autónoma de Barcelona. Recuperado en 21 de febrero de 2020, de

2. Álvarez-Díaz, J. (2007). La controversia sobre la vivisección. Acta bioethica, 13, 53-60.

3. Belmont Report (1979). Ethical Principles and Guidelines for the Protection of Human Subjects of Research. Recuperado en 10 de febrero de 2020 de

4. Boada, M.; Colom, A. y Castellò, N. (2011) La Experimentación Animal, Universidad Autónoma de Barcelona. Recuperado de 11 de febrero de 2020 de

5. Brinkmann, S. (2011). Psychology as a Moral Science. Perspectives on Normativity. New York: Springer.

6. Bombino, L., de Armas, A. y Porto, M. (2009). Por una nueva ética. La Habana: Félix Varela.

7. Bombino, L, Núñez, J, Fernández, L, Nodarse, N, Díaz, T., et al (2011). El saber ético de ayer a hoy. La Habana: Félix Varela.

8. Beauchamp, T. y Childress, J. (2011). Principios de Ética Biomédica, de Tom L. Beauchamp y James F. Childress. Bioètica \& Debat, 17, 1-7.

9. Caballero, M. (2016). Estrategia ante el reto bioético del paciente crítico. En: M. Ruiz (coord.). Temas selectos de Conbioética. Gaceta Conbioética. Comisión Nacional de Bioética. México: Secretaría de Salud.

10. Cardozo, C., Mrad de Osorio, A. (2008). Ética en investigación con animales: Una actitud responsable y respetuosa del investigador con rigor y calidad científica. Revista Latinoamericana de Bioética, 8, 46-71.

11. Castoriadis, C. (1988). Los dominios del hombre: las encrucijadas del laberinto. Barcelona: Gedisa.

12. Cash, R., Wikler, D., Saxena, A., Capron, A. (2010). A Casebook on Ethical Issues in International Health Research Geneva: World Health Organization, 2010.

13. Custer, G. (1994). Can universities be liable for incompetent grads? APA, Monitor, 7.

14. De Aluja, A. (2002). Animales de laboratorio y la Norma Oficial Mexicana (NOM-062-ZOO- 1999). Gaceta Médica Méxicana, $138(3)$.

15. De Duve, C. (1974). Facts. Recuperado en 10 de febrero de 2010 en 
16. De la Torre, M. y Pardo, R. (2018). Guía para la intervención psicológica. Colegio oficial de Psicólogos de Madrid. Recuperado en 11 de diciembre de 2019 de

17. Dewey, J. (2003). Viejo y nuevo individualismo. Pensamiento contemporáneo 73. Paidós: Barcelona.

18. Fernández H. J. y Heuze De Icaza, Y. (2007) El programa interno para el cuidado y uso de los animales de laboratorio en las instituciones biomédicas docentes, de investigación científica e industria farmacéutica. Acta Bioéthica, 13, 17-24. Recuperado en 11 de febrero de 2020 de

19. Foucault, M. (1976). Vigilar y Castigar. El Nacimiento de la Prisión. México: Siglo XXI Editores.

20. García, P. y Ruíz, A. (2010). Existencia y Libertad. México: UNAM-SIGLO XXI. Enciclopedia de Conocimientos Fundamentales.

21. Institutional Framework of Teaching (1988). Marco Institucional de Docencia. Recuperado en 10 de febrero de 2020 en

22. Instituto Nacional de Salud Pública (2019). Consentimiento Informado. Recuperado en 21 de febrero de 2020 de

23. Keith- Spiegel, P. (1991). The complete guide to graduate school admission. New Jersey: Hillsdale Lawrence Erlbaum.

24. Keith- Spiegel, P., Tabachnick, B., y Spiegel, G. (1994). When demand exceeds supply: Second order criteria in graduate school selection criteria. Teaching of Psychology, 21, 79-85.

25. Koocher, G. y Keith-Spiegel, P. (1998). Ethics in Psychology. New York: Oxford University Press.

26. Küng, H. y Kuschel, K. (2006). Ciencia y ética mundial. Madrid: Trotta Editorial.

27. Murray, J. \& Thomas, E. (1990). The Nobel Prize in Physiology or medicine. Recuperado en 10 de febrero de 2020 en

28. NORMA Oficial Mexicana NOM-062-ZOO-1999, Especificaciones técnicas para la producción, cuidado y uso de los animales de laboratorio. Recuperado en 11
29. Ochs, E. y Schieffelin, B. (1984). Language acquisition and socialization: three developmental stories and their implications." In R. Shweder and R. Levine (eds.), Culture theory: essays on mind, self and emotion, 276-320. New York: Cambridge University Press.

30. Organización Panamericana de la Salud, (2014). Estudios de caso de la investigación internacional en salud. Washington, D. C.: OPS 2014.

31. OMS (2014). Ethical Challenges in drug epidemiology: issues, principles and guidelines. Global Assessment Programme on Drug Abuse (GAP) Toolkit Module 7. New York: United Nations Office on Drugs and Crime.

32. Potter, V. (1971). Bioethics bridge to the future. New York: Prebtis Hall.

33. Regulation of the General Health Law on Health Research (2005). Reglamento de la Ley General de Salud en Materia de Investigación para la Salud. Recuperado en 11 de febrero de 2020 de

34. Rodríguez, M. (2005). Sobre ética y moral. Revista Digital Universitaria, 6, 1067-6079.

35. Rodríguez, Y. (2007). Ética de la investigación en modelos animales de enfermedades humanas. Acta bioethica, 13, 25-40.

36. Ross, R. (1902). Researches on malaria. Recuperado en 10 de febrero de 2020, de

37. Russell, W. y Burch R. (1959). The Principles of Humane Experimental Technique. Methuen: London.

38. Thelier, M. (1951). The Development of vaccines against Yellow Fever. Recuperado en 10 de febrero de 2020 en

39. The Nobel Prize (2020). Stockholm, Sweden: Recuperado de

40. UNESCO, (2005). Guía No. 1. Creación de Comités de Bioética. Francia: Organización de las Naciones Unidas para la Educación la Ciencia y la Cultura.

41. Valor UNAM (2015). Recuperado
This work is licensed under Creative Commons Attribution 4.0 License

To Submit Your Article Click Here: Submit Manuscript

DOI: $10.31579 / 2637-8892 / 068$
Ready to submit your research? Choose Auctores and benefit from:

$$
\begin{aligned}
& \text { * fast, convenient online submission } \\
& \text { rigorous peer review by experienced research in your field } \\
& \text { rapid publication on acceptance } \\
& \text { * authors retain copyrights } \\
& \text { * imique DOI for all articles } \\
& \text { immediate, unrestricted online access }
\end{aligned}
$$

At Auctores, research is always in progress.

Learn more www.auctoresonline.org/journals/psychology-and-mentalhealth-care 